\section{Mother-to-child transmission of HIV in Brazil during the years 2000 and 2001: results of a multi-centric study}

\author{
Transmissão vertical do HIV no Brasil em 2000 e \\ 2001: resultados de um estudo multicêntrico
}

\author{
${ }_{1}^{1}$ Departamento de Pediatria, \\ Universidade Federal de São \\ Paulo, São Paulo, Brasil. \\ 2 Departamento de \\ Infectologia, Sociedade \\ Brasileira de Pediatria, Rio \\ de Janeiro, Brasil. \\ 3 Other members listed at the \\ end of the paper. \\ Correspondence \\ R. C. M. Succi \\ Disciplina de Infectologia \\ Pediátrica, Departamento \\ de Pediatria, Universidade \\ Federal de São Paulo. \\ Rua Pedro de Toledo 924, \\ São Paulo, SP \\ 04039-003, Brasil. \\ succi@picture.com.br
}

\begin{abstract}
The objective of this study was to assess motherto-child transmission rates of HIV in Brazil during the years 2000 and 2001, and to identify the maternal and neonatal variables that were associated with this transmission. It was a crosssectional, observational study with retrospective data obtained from patient medical records. The children were followed at 63 medical sites situated in five geographical macro-regions of the country (20 States and the Federal Capital). Children enrolled were those that were born of $H I V$-infected mothers and it was necessary for the mothers to present documented proof of $H I V$-infection before or during pregnancy, at time of delivery or in the first three months after delivery. There were 2,924 children enrolled and mother-to-child transmission rates of HIV were $8.6 \%$ (95\% CI: 7.2-10.2) for the year 2000 and 7.1\% (95\%CI: 5.8-8.6) for the year 2001. The following variables were associated with lower mother-to-child transmission rates of HIV: elective cesarean section, diagnosis of mother's infection before or during pregnancy, access to HIV viral load and T CD4+ lymphocyte count during prenatal care, greater birth weight and avoidance of breastfeeding.
\end{abstract}

Vertical Disease Transmission; HIV; Prenatal Care
Regina Célia de Menezes Succi 1,2 Grupo de Estudo da Sociedade Brasileira de Pediatria para Avaliar a Transmissão MaternoInfantil do $\mathrm{HIV}^{3}$

\section{Introduction}

As of June 2005 there had been 11,901 cases of AIDS in children under 13 years reported to the Brazilian National STD/AIDS Program (PNDST/ AIDS) of the Ministry of Health and vertical transmission was responsible for $83.7 \%$ of these cases 1 . Despite the undeniable reduction in recent years in the reporting of mother-to-child transmission of HIV: 1,002 cases in 1997 versus 390 in $2004^{2}$, it is still not sufficiently clear how the recommendations from the PNDST/AIDS for the reduction of HIV vertical transmission are being applied and what are their impact in the various regions of the country. In Brazil, the AIDS incidence rate continues to be high (17.1 cases per 100,000 in 2004), basically due to its tendency for growth among the female population; there has been a decline among children of less than 5 years and in males, a reduction in AIDS rates among younger people from 13 to 29 years old, and an increase among older people, principally from 40 to 59 years old. Among women, since 1988, there has been a tendency for stabilization among people aged 13 to 24 years old, but with a persistent growth in practically all other age groups 1 .

The reporting of seropositive pregnant women became compulsory in Brazil in 2000, and it has been increasing over the time period under analysis, but for the year 2004, of the estimated 12,644 seropositive pregnant women, only around $52 \%$ were reported 1 . 
In 1994, with the publication of the findings of protocol PACTG 076 2, it became evident that a significant reduction in HIV transmission from infected mothers to their children was possible through AZT prophylaxis for pregnant mothers and newborns. The rates of vertical HIV transmission that had, in the absence of any intervention until 1994, varied from $12 \%$ to $42 \% 3$, fell significantly to rates of less than $2 \%$ in those countries that, in addition to this and other therapeutic regimens (combined regimens), implemented pre-natal HIV testing and counseling and avoidance of breastfeeding 4,5,6,7.

Reducing vertical HIV transmission has been a goal of health programs in various parts of the world 8. In Brazil, the guarantee of availability of antiretroviral medication for all patients with therapeutic indications, the offer of anti-HIV testing during gestation, the possibility of monitoring viral load and CD4 lymphocyte count, and the access to special services, has had a great impact on the quality of life of those individuals infected with HIV and significantly reduced mother-to-child transmission of HIV 9,10,11,12. The access to the benefits of antiretroviral therapy, however, still do not reach all seropositive pregnant women 13. Making available HIV diagnosis, and the prophylactic measures needed, to all pregnant women is a huge challenge in many regions of the country.

The objective of this study is to estimate HIV vertical transmission rates in Brazil in the years 2000 and 2001, and the maternal and newborn variables associated with these rates in different regions of the country.

\section{Material and methods}

The necessity of obtaining data representative of the Brazilian vertical HIV transmission reality motivated the Comitê de Doenças Infecciosas, Sociedade Brasileira de Pediatria [Infeccious Disease Commitee, Brazilian Pediatrics Society] to organize a study group with representatives from various parts of the country. The choice of participating health services was made through contacts of the Brazilian Pediatrics Society with places that were known to attend the greatest number of cases in each region.

The Grupo de Estudo da Sociedade Brasileira de Pediatria para Avaliar a Transmissão MaternoInfantil do HIV is a multicentric group created in 2001 by the Chapter of Infectology of the Sociedade Brasileira de Pediatria, with the purpose of estimating the extent of HIV vertical transmission in Brazil. The group consists of professionals from all over the country who follow children born to mothers infected with HIV and participating services (in which these professionals are inserted and from where the data are collected), characterized by providing clinical and laboratorial follow up to these children.

To carry out this study, doctors from 63 health services located in the five macro regions of the country (twenty states and the Federal District) participated. The distribution of the services according to geographic regions of the country was the following: 4 services in the Northern Region - States of Amazonas, Pará, and Amapá; 8 in the Northeastern Region - States of Alagoas, Bahia, Ceará, Maranhão, Paraíba, Pernambuco, and Sergipe; 4 in the Central Western Region - States of Goiás, Mato Grosso, and the Federal District; 39 in the Southeastern Region - States of Espírito Santo, Minas Gerais, Rio de Janeiro, and São Paulo; and 7 in the Southern Region - States of Rio Grande do Sul, Paraná, and Santa Catarina.

The participating medical services were classified into the following categories, according to their administrative structures: 1 basic healthcare provider (UBS), 19 university hospitals, 26 specialized STD/AIDS clinics, 6 general hospitals, and 11 others characterized as other medical services (private, mixed etc.). The necessity for specialized medical care for these children was probably what characterized the participating services, with the majority of them being either specialized in STD/AIDS, or university hospitals.

This study is a cross-sectional observational one, with retrospective data obtained from the medical records of the participating services. When possible, information was also collected from the medical records of the mothers of the children included in the research (when both mother and child were attended by the same service). A databank was created for the collection of information obtained about the mother (age, time of HIV diagnosis, exposure category, prenatal care, antiretroviral therapy, mode of delivery, length of gestation) and the child (birth-weight, breastfeeding, HIV infection).

To define the population studied, the following inclusion criteria were established: children born during the period from January 1, 2000 to December 31, 2001 whose mothers had a documented HIV infection before or during gestation, at the moment of admission for childbirth or in the first three months after childbirth. Only the mother-child pairs in whom it was possible to define the status of the infection of the child (infected or not infected) were included in the study. The inability to define the situation of the HIV infection by the end of the data collection period (June 2003) was considered a criterion for exclusion. 
Children were considered not infected if they presented no clinical symptoms of AIDS and tested negative (or had no reaction to) for two of the following tests: test for HIV antibodies carried out after 6 months of life, or two quantifications of viral RNA with results below the detection level, at least one of them taken after the fourth month of life, or two negative tests of DNA through polymerase chain reaction (PCR) carried out after the second week of life.

Children considered infected were those who presented clinical symptoms indicating AIDS and/or presented positive/reagent results on two of the following tests, taken at different times: test for HIV antibodies carried out after the 15th month of life, or quantification of viral RNA with a result above detection level at least one of which was realized after the first month of life, or a positive PCR realized after the second week of life.

The definition of the HIV infection in children was slightly modified in relation to the Guia de Tratamento Clínico da Infecção pelo HIV em Crianças (Guide for Treatment of the HIV Infection in Children), published by the Brazilian Ministry of Health 14 with the object of defining, with certainty, and as early as possible, the infectious status of children, because in some regions of the country it is difficult to easily obtain exam results.

\section{Prenatal care}

For the purposes of this study, prenatal care was considered to be any number of medical or nursing consultations that women have during gestation. This definition was the result of interviewing a large number of women, who were asked to answer yes or no to the following question: did you have prenatal care?

"Transmitting mothers", for the purposes of this study, were considered to be those whose children (included in the study) were defined as being infected with HIV. Non-transmitting mothers were considered to be those whose children were defined as not being HIV-infected.

\section{Use of antiretroviral therapy during} gestation, during labor or for the newborn

For each woman studied it was possible to identify the moment that the use of antiretroviral therapy began (gestation, labor, post-labor), but sometimes the drugs used and their dosage were not well-defined. Information about the use of any antiretroviral therapy in any moment of gestation, during labor, or in the neonatal period even though it was not possible to identify the specific drugs used, their dosage, or length of treatment, was considered positive.
Any information about exams utilized in the monitoring of the HIV infection carried out during gestation (exams quantifying the viral load of HIV and CD4+/CD8+ T lymphocyte count), even when their results or the time of their realization were not available in medical records, was defined as access to prenatal HIV infection testing.

A record of any maternal breastfeeding at any time and for any duration was defined as "maternal beastfeeding present".

The transmission rate was expressed as a percentage with the respective confidence interval at $95 \%(95 \% \mathrm{CI})$. The categorical variables (time of HIV infection diagnosis, prenatal exams, use of antiretroviral therapy during gestation, type of birth, realization of exams during gestation) were expressed as a number and percentage, and the numerical values (age of mothers at childbirth) were expressed as an average \pm standard deviation.

In univariate analysis, the association between the transmission rate and each of the demographic and clinical variables used chisquare tests, and in cases in which the frequency expected was less than five Fisher's exact test. In multivariate analysis, logic regression was used to evaluate the association between the status of the child's infection and the different characteristics of the mothers and children.

In all the statistical analysis a significance level of $5 \%$ was adopted, in other words, results that presented a $\mathrm{p}$ value less than $5 \%(\mathrm{p}<0.05)$ were considered significant.

The study was approved by the Commission of Ethics in Research of the Universidade Federal de São Paulo [Federal University of São Paulo] and the representatives of each service signed an agreement, taking responsibility for the collection and confidentiality of the data. Services with local research ethics committees also obtained local approval.

\section{Results}

Among 3,421 mother-child pairs that began the follow-up in the participating heath care services only $2,924(85.5 \%)$ were included for analysis. The reasons for non-inclusion of mother-child pairs were the following; abandonment and/or transfer to another health service (167 cases), death without confirmation of infectious status (13 cases), and undefined infectious status until the end of data collection period (317 cases). The HIV vertical transmission rate observed was $8.6 \%$ among children born in the year 2000 (95\%CI: $7.2-10.2)$ and $7.1 \%$ among children born in 2001 (95\%CI: 5.8-8.6) (Table 1). In the year 2000 the 
Number of mother-child pairs included and infected children per year of birth and region of origin. Brazil, $2000-2001$.

\begin{tabular}{|c|c|c|c|c|}
\hline \multirow[t]{2}{*}{ Region } & \multicolumn{2}{|c|}{ Year 2000} & \multicolumn{2}{|c|}{ Year 2001} \\
\hline & $\begin{array}{c}\text { Mother-child pairs } \\
\mathrm{n}\end{array}$ & $\begin{array}{c}\text { Infected children } \\
\text { n (\%) }\end{array}$ & $\begin{array}{c}\text { Mother-child pairs } \\
\mathrm{n}\end{array}$ & $\begin{array}{c}\text { Infected children } \\
\text { n (\%) }\end{array}$ \\
\hline Southeast & 914 & $84(8.2)$ & 874 & $61(7.0)$ \\
\hline South & 343 & $25(7.3)$ & 366 & $16(4.4)$ \\
\hline Central-West & 82 & 4 (4.9) & 73 & $4(5.5)$ \\
\hline Northeast & 89 & $7(7.9)$ & 112 & $16(14.3)$ \\
\hline North & 34 & $6(17.6)$ & 37 & 7 (18.9) \\
\hline Total & 1,462 & $126(8.6)$ & 1,462 & $104(7.1)$ \\
\hline
\end{tabular}

transmission rate varied from $4.9 \%$ (CentralWestern Region) to $17.6 \%$ (Northern Region), but there were no significant differences in rates among the five regions. In 2001 the transmission rate varied from $4.4 \%$ (Central-Western Region) to $18.9 \%$ (Northern Region); the Southeastern, Southern, and Central-Western Regions had lower rates of transmission than the Northern and Northeastern Regions.

The characteristics of the mothers and children according to year of children's birth and HIV vertical transmission can be seen in Table 2 .

The age of the mothers varied from 13 to 47 years, the average age \pm standard deviation being distributed in macro-regions in this way: $27.9 \pm 5.9$ years in the Southeastern Region; 26.3 \pm 5.8 years in the Southern Region; $25.5 \pm 5.5$ years in the Central-Western Region; $26.8 \pm 5.8$ years in the Northeastern Region; and $26.0 \pm 6.5$ years in the Northern Region. The average age of mothers was higher in the Southeastern Region, but the average age in the five regions did not differ among the transmitting mothers and the non-transmitting mothers. Only 148/2,924 (5.1\%) of the mothers were 18 years or younger and $321 / 2,924$ (11\%) were 20 years or younger. When the group of mothers is stratified by age ( $\geq 30$ years or $<30$ years) there was no significant difference between transmission rates.

The diagnosis of the HIV infection was made before or during pregnancy in 1,242 women (89.3\%) in the year 2000 and in 1,266 women (90.4\%) in the year 2001. Women who had the diagnosis made before or during pregnancy presented lower vertical transmission $(5.2 \%$ in 2000 and $4.3 \%$ in 2001) than those whose diagnosis was made during labor or after birth $(32.9 \%$ in 2000 and $26.9 \%$ in 2001). In the Southeastern and Southern Regions there was a greater proportion of diagnoses made before or during gestation when compared with other regions; diagnoses made before or during pregnancy were associated with lower rates of HIV vertical transmission in the two years studied and in all the regions studied, with the exception of the Northern Region in 2000 and the Central-Western Region in 2001.

Information about prenatal care was collected for 2,712 mothers. Among them 1,286/1,361 (94.5\%) in 2000 and 1,295/1,351 in 2001 received prenatal care. The Central-Western and Northern Regions were the ones where a greater proportion of mothers received prenatal care. Lower rates of mother-to-child HIV transmission were associated with prenatal care in all regions analyzed during the two years studied, with the exception of the Northern Region in 2000 and the Southeastern and Northeastern Regions in 2001. Mother-to-child HIV transmission among women with/without prenatal care was $6.5 \% / 28.7 \%$ in 2000 and $5.6 \% / 18 \%$ in 2001.

The use of antiretroviral therapy during pregnancy was observed in 2,305 women $(1,143$ in 2000 and 1,162 in 2001), $81.4 \%$ and $82.5 \%$ respectively for women with this information available. The Southeastern, Southern, and Central-Western Regions presented the greatest proportion of antiretroviral therapy use during pregnancy $(82.9 \%)$ compared to the Northeastern and Northern Regions (71.8\%). The Northern Region had the least use of antiretroviral therapy during gestation compared to the other regions. The vertical transmission rate was significantly lower among infants whose mothers had used antiretroviral therapy during pregnancy $(81 / 2,305=$ $3.5 \%)$ compared to those without this intervention $(131 / 508=25.8 \%)$. The HIV vertical transmission rate was of $4.2 \%$ and $2.8 \%$ respectively, in the two years studied, among mothers that had used antiretroviral therapy; mothers who had not used antiretroviral therapy had transmission 
Number and proportion (\%) of infected children, according to the year of birth and selected characteristics of mothers and children. Brazil, $2000-2001$.

\begin{tabular}{|c|c|c|c|c|c|c|}
\hline & & Year 2000 & & & Year 2001 & \\
\hline & $\begin{array}{c}\text { Women } \\
\text { included } \\
n\end{array}$ & $\begin{array}{l}\text { Children } \\
\text { infected } \\
n(\%)\end{array}$ & $p$ * & $\begin{array}{c}\text { Women } \\
\text { included } \\
n\end{array}$ & $\begin{array}{l}\text { Children } \\
\text { included } \\
n(\%)\end{array}$ & $p$ * \\
\hline Age at delivery (years) & & & 0.143 & & & 0.928 \\
\hline$<30$ & 846 & $76(9.0)$ & & 894 & $56(6.3)$ & \\
\hline$\geq 30$ & 465 & $31(6.7)$ & & 440 & $27(6.1)$ & \\
\hline Time of diagnosis & & & $<0.001$ & & & $<0.001$ \\
\hline Before or during gestation & 1,242 & $65(5.2)$ & & 1,266 & $54(4.3)$ & \\
\hline At delivery or post-delivery & 149 & $49(32.9)$ & & 134 & $36(26.9)$ & \\
\hline Prenatal & & & $<0.001$ & & & $<0.001$ \\
\hline Yes & 1,286 & $84(6.5)$ & & 1,295 & $73(5.6)$ & \\
\hline No & 101 & $29(28.7)$ & & 111 & $20(18.0)$ & \\
\hline Use of antiretroviral therapy during gestation & & & $<0.001$ & & & $<0.001$ \\
\hline Yes & 1,143 & $48(4.2)$ & & 1,162 & $33(2.8)$ & \\
\hline No & 261 & $71(27.2)$ & & 247 & $60(24.3)$ & \\
\hline Mode of delivery & & & $<0.001$ & & & $<0.001$ \\
\hline Vaginal & 518 & $65(12.5)$ & & 536 & $54(10.1)$ & \\
\hline Non-elective caesarean section & 357 & $32(9.0)$ & & 308 & $18(5.8)$ & \\
\hline Elective caesarean section & 520 & $12(2.3)$ & & 567 & $22(3.9)$ & \\
\hline Viral load and CD4 count during gestation & & & $<0.001$ & & & $<0.001$ \\
\hline Yes & 693 & $10(1.4)$ & & 766 & $15(2.0)$ & \\
\hline No & 357 & $83(23.2)$ & & 317 & $62(19.6)$ & \\
\hline Gestational age (weeks) & & & $<0.001$ & & & 0.515 \\
\hline$<37$ & 132 & $21(15.9)$ & & 151 & $11(7.3)$ & \\
\hline$\geq 37$ & 672 & $39(5.8)$ & & 747 & $44(5.9)$ & \\
\hline Birth weight (grams) & & & $<0.001$ & & & $<0.001$ \\
\hline$<2,500$ & 290 & $54(18.6)$ & & 338 & $44(13.0)$ & \\
\hline$\geq 2,500$ & 1,172 & $72(6.1)$ & & 1,123 & $60(5.3)$ & \\
\hline Breastfeeding & & & $<0.001$ & & & $<0.001$ \\
\hline Yes & 105 & $45(42.9)$ & & 77 & $26(33.8)$ & \\
\hline No & 1,316 & $72(5.5)$ & & 1,351 & $68(5.0)$ & \\
\hline
\end{tabular}

* Chi-square test.

rates of $27.2 \%$ and $24.3 \%$ respectively, in the two years studied.

HIV transmission was significantly modified depending on the mode of delivery: in the two years evaluated caesarian section was found to be associated with lower rates of vertical transmission. Vaginal delivery, which was realized in $518 / 1,395(37.1 \%)$ women in the year 2000 and in $536 / 1,411$ (38\%) in 2001 , was found to be associated with higher vertical transmission in the Southeastern, Southern, and Northeastern Regions in 2000, and the Southeastern Region in 2001. The rate of vaginal delivery was lower in the Central-Western (25.6\%), Southern (37.3\%), and South eastern (35\%) Regions than in the Northern (47.8\%), and Northeastern (42.7\%) Regions.
Access to exams for evaluating the HIV infection status (quantification of viral load and $\mathrm{T}$ lymphocytes CD4+/CD8+ count) was obtained for $693 / 1,462(47.4 \%)$ of the women in the year 2000 and $766 / 1,462$ (52.4\%) in 2001. The access to these exams proved most frequent in the Southeastern, Southern, and Central-Western Regions and was linked to lower vertical HIV transmission rates in the Southeastern and Southern Regions in the year 2000, and the Southeastern, Southern, and Northern Regions in 2001.

The gestational age was known in 1,702 children evaluated and $16.6 \%$ of them were premature. Lower rates of vertical HIV transmission were found to be associated with full term gestation $(5.8 \%)$ when compared to premature gesta- 
tion $(10.9 \%)$. Of the children with known birth weight, 628/2,923 (21.5\%) weighed $<2,500 \mathrm{~g}$. The vertical HIV transmission rate was significantly higher (15.6\%) among babies weighing $<2,500 \mathrm{~g}$ at birth when compared with those weighing $\geq$ $2,500 \mathrm{~g}(5.8 \%)$.

Information about breastfeeding was obtained for 2,849 children, 182 of whom received mother's milk. The duration of breastfeeding varied from one to 719 days (mean 112 days, median 28 days). The majority of nursing mothers $(102 / 182=56 \%)$ were diagnosed with HIV during or after delivery, but $24.7 \%$ of them $(45 / 182)$ were diagnosed before or during pregnancy. The proportion of women from each region who breastfed their babies was: $5.7 \%$ of the women from the Southeastern Region, $2.6 \%$ from the Southern Region, $7.7 \%$ Central-Western Region, $14.4 \%$ from the Northeastern Region, and 2.8\% from the Northern Region.

Use of antiretroviral therapy during childbirth was recorded in 2,208 women $(1,073$ in 2000 and 1,135 in 2001). The use of antiretroviral therapy during childbirth (univariate analysis) was found to be associated with lower motherto-child transmission rates of HIV in both years studied (4.9\% in 2000 and $3.3 \%$ in 2001 ), when compared to women who did not receive this therapy (23.4\% in 2000 and $20.2 \%$ in 2001). However, this difference was not evidenced in the Central-Western Region in 2000, nor in the Central-Western and Northeastern regions in 2001. Almost all the newborns received AZT in the neonatal period $(91.6 \%$ of babies born in 2000 and $93.9 \%$ of those born in 2001); no significant association of such variable with vertical HIV transmission rates was found.

When the regimen of antiretroviral therapy used was analyzed, it was observed that 699 women (363 in 2000 and 336 in 2001) did not receive any type of antiretroviral therapy during gestation, 983 received AZT mono-therapy, 431 received two drugs, and 811 received three or more drugs. There was a greater proportion of babies infected among mothers who did not receive any antiretroviral therapy (22.6\%), compared with those who received mono-therapy $(5.4 \%)$, double therapy $(2.3 \%)$, or with those who received three or more drugs and had the lowest proportion of infected babies (1.1\%). When the rate of transmission among women that had received two drugs was compared with that of women who had received three or more the transmission rates were similar, but on comparing the infection rates among babies whose mothers had received mono-therapy with those who had received double or triple therapy a significant statistical difference was noted (Table 3 ).

After the data were subjected to univariate analysis, the variables with no statistical significant association with the outcome were removed, and multivariate analysis was done. A logistic regression of all the variables studied was done and afterwards all variables that did not demonstrate a significant association with the outcome and had a value of $\mathrm{p}>0.10$ (mother's age, prenatal, use of antiretrovirals during gestation, and gestational age) were removed, obtaining an adjusted model depicted in Table 4. In agreement with this adjustment, independent factors associated with vertical HIV transmission were as follows: time of mother's diagnosis; mode of delivery; access to viral load and T lymphocyte CD4 exams during gestation; birth weight, and breastfeeding.

Table 3

Number of mother-child pairs included and children infected per year of birth and according to the antiretroviral regimen utilized by the mother. Brazil, 20002001

\begin{tabular}{|c|c|c|c|c|c|c|}
\hline \multirow[t]{2}{*}{ Antiretroviral regimen } & \multicolumn{3}{|c|}{ Year 2000} & \multicolumn{3}{|c|}{ Year 2001} \\
\hline & $\begin{array}{c}\text { Mother-child pairs } \\
\mathbf{n}\end{array}$ & $\begin{array}{l}\text { Infected children } \\
\text { n (\%) }\end{array}$ & $p^{*}$ & $\begin{array}{c}\text { Mother-child pairs } \\
\mathrm{n}\end{array}$ & $\begin{array}{l}\text { Infected children } \\
\text { n (\%) }\end{array}$ & $p^{*}$ \\
\hline & & & $<0.001$ & & & $<0.001$ \\
\hline None & 363 & $84(23.1)$ & & 336 & $74(22.0)$ & \\
\hline Monotherapy & 571 & $33(5.8)$ & & 412 & $20(4.9)$ & \\
\hline Dual therapy & 225 & $4(1.8)$ & & 206 & $6(2.9)$ & \\
\hline Three or more drugs & 303 & $5(1.7)$ & & 508 & $4(0.8)$ & \\
\hline
\end{tabular}

* Chi-square test. 
Factors independently associated with mother-to-child transmission of HIV according to the findings of multivariate logistic regression. Brazil, 2000-2001.

\begin{tabular}{lcc}
\hline & Odds ratio & $\mathbf{9 5 \%} \mathbf{C l}$ \\
\hline Time of mother's diagnosis (at delivery, post-delivery/before or during pregnancy) & 1.78 & $1.13-2.80$ \\
Mode of delivery & 1.92 & $1.14-3.24$ \\
$\quad$ Vaginal (vs. elective caesarean section) & 1.82 & $1.02-3.24$ \\
Post-labor caesarean (vs. elective caesarean section) & 7.08 & $4.26-11.79$ \\
Viral load and CD4 count during gestation (No/Yes) & 1.79 & $1.19-2.69$ \\
Birth weight $(<2,500 \mathrm{~g} / \geq 2,500 \mathrm{~g})$ & 2.49 & $1.55-4.02$ \\
Breastfeeding (Yes/No) & & \\
\hline
\end{tabular}

\section{Discussion}

The data obtained through this broad study, the first multicenter study that evaluated mother-to-child transmission of HIV in the entire country, probably reflects what happened in the country as a whole. Notification of the HIV infection is not compulsory, and the notification of HIV-infected pregnant women and exposed newborns, initiated in 2000 , is still incipient, having amounted to a little more than half the estimated cases in 20041 . The proportional distribution of cases in mother-child pairs included by region is similar to the distribution of cases in adults reported to the Ministry of Health in the years 2000 and 2001 1: 3.1\% of the cases reported were in residents of the Northern Region; $8.9 \%$ in the Northeastern Region; $57.1 \%$ in the Southeastern Region; $22.9 \%$ in the Southern Region; and 5.6\% in the Central-Western Region. Despite being quite efficient, the notification of AIDS cases in the country may not precisely represent the number of pregnant women infected and newborns exposed, but as it is available data, it is considered applicable for estimating the proportion of pregnant women in each region.

Mother-to-child transmission of HIV depends on various factors (maternal, viral, and fetal) and the rates of transmission vary in different populations 15,16 . In developed countries, as a consequence of interventions in pregnant women, mother-to-child transmission of HIV has fallen to rates of less than $2 \%$, but in developing countries this goal has not yet been attained.

Some groups of Brazilian authors have shown that, in certain health services and municipalities, the adoption of strategies that increase not only prenatal care, but also offer of a voluntary HIV test, the use of antiretroviral prophylaxis in pregnant women and their infants, in addition to avoidance breastfeeding, have managed to reduce the rates of vertical HIV transmission $9,10,11,12,13,14,17,18,19$. On the other hand, the only multi-centric Brazilian study previously published (evaluating data from health services in the São Paulo State, Brazil, documents the follow-up of 434 children exposed to HIV, born between January 1988 and April 1993) found rates of vertical HIV transmission to be $16 \%$ (95\%CI: 13.0-20.0) 20.

Taking into account the findings from this study, it can be said that mother-to-child transmission of HIV has diminished by more than $50 \%$ in recent years, falling from a rate of $16 \%$ in the period from 1998 to 199320 to $7.1 \%$ in 2001 . Evaluation of the two periods, done by the reference service of the city of Riberão Preto (São Paulo State), revealed a reduction of $44.3 \%$ in the transmission rate when comparing the periods 1988-1993 and 1996-1999 21. Meanwhile, in a developed country (the United States), a comparison of the two periods revealed an even greater fall: from $18.1 \%$ in the period $1990-1992$ to $1.6 \%$ in the period 1999-2000 22 .

Even though the national mother-to-child transmission rate of HIV evaluated in 2001 (7.1\%) is still elevated, this finding clearly shows that the strategy developed in recent years by the PN DST/AIDS (STD and AIDS Program) of the Ministry of Health has been effective. Only including children whose HIV infection status has been confirmed could be considered as a potential cause for error in the appraisal of the HIV infection rate, but, on the other hand, the majority of children that had not been followed up until their infectious condition was defined were probably asymptomatic, or uninfected, and if these children had been included in the study the transmission rate observed would have been lower. 
Other possible factors that could cause error in the evaluation of vertical HIV transmission rate should be considered: the time of antiretroviral therapy introduction, the quality of prenatal care, and the process of selecting participating health services.

Aside from these considerations, the access to health assistance is different in each region of the country for infected pregnant women, as well as for exposed children. Thus isolated facts may change the time in which the diagnosis of the HIV infection in the woman and the child is made: the quality of prenatal care; the utilization of different therapeutic regimens to treat the pregnant woman and prophylaxis for vertical transmission of the virus; availability of exams to evaluate vertical HIV transmission risks; and co-infections of the pregnant woman which may favor vertical HIV transmission.

Only $5.1 \%$ of the women evaluated were 18 years or under, and in the states of the Southeastern Region the median age was over 27 years, suggesting that the HIV infection is occurring after adolescence, or that younger women, when infected, are able to postpone, or even avoid, pregnancy. Other Brazilian authors found similar maternal ages in studies of mother-to-child HIV transmission: 16 to 43 years (median 26.1 years) in the Rio de Janeiro State 17, 13 to 42 years (median 24 years) in the Mato Grosso State 18, and 16 to 42 years (median 27.3 years) in the city of Santos, São Paulo State 12. In Brazil, there has been a stabilizing tendency in the infection rates among women between 13 and 24 years old, with persistent growth in practically all other age groups 1 , and the data observed in this study reflect this increase in the rates among women over 27 years old.

An overwhelming majority of women informed having access to prenatal care $(94 . \%$ in 2000 and $95.8 \%$ in 2001), but notwithstanding, the proportion of women whose HIV infection diagnosis was made before or during pregnancy was lower than the proportion of women who had had prenatal care $(89.3 \%$ in 2000 and $90.4 \%$ in 2001). The fact that any number of consultations was considered "prenatal care" suggests that in many cases prenatal care was insufficient (in time and/or quality) to ensure the offer of HIV testing in all women and availability of the necessary prophylactic measures. The definition used in this study for prenatal care as being "any number of consultations by a doctor or nurse for follow-up during gestation", could result in an underestimation of the effect of this variable on vertical HIV transmission rates.

The reduction of mother-to-child transmission of HIV when effective antiretroviral ther- apy is made available has been demonstrated in various studies $7,20,21,23,24$. Antiretroviral use both in treating the mother's condition and preventing mother-to-child transmission, has been increasing in the last decade in all regions of the country, but the use of medication is far from uniform. In this study 699 women $(20 \%$ of those for whom information was available) did not receive any antiretroviral therapy during pregnancy, again demonstrating that, although it can be verified that $95.2 \%$ of pregnant women received some kind of prenatal care, this care was not sufficient to guarantee access to antiretrovirals prophylaxis during gestation and delivery. Similarly, diagnosis of HIV infection before or during pregnancy (which occurred in $89.9 \%$ of pregnant women studied) did not guarantee access to this measure.

The Southeastern, Southern, and CentralWestern Regions, where the use of antiretroviral therapy during pregnancy was greatest, presented lower vertical HIV transmission rates. The Northern Region, which, compared to other regions, had the lowest proportion of antiretroviral therapy use during pregnancy, also had the highest rates of vertical HIV transmission.

The age of the mother at the time of delivery (in the two years studied) and the gestational age (in 2001) were not found to be associated with a higher vertical HIV transmission rate among the cases evaluated using univariate analysis. The following variables were considered to be independent risk factors for mother-child HIV transmission in both of the years studied: late diagnosis of maternal infection (during delivery or after delivery), absence of prenatal care, no use of antiretroviral therapy during gestation, mode of delivery (vaginal delivery), no exams to follow the progress of the HIV infection (viral load and T lymphocytes CD4 count exams), birth weight of $<2,500 \mathrm{~g}$, and breastfeeding.

Caesarian section before the beginning of labor or rupture of membranes (elective caesarian) is an intervention that has been proven to be useful in the prevention of vertical HIV transmission in pregnant women who have not received antiretroviral therapy or have only received AZT mono-therapy, however its utility among women who are already using highly effective antiretroviral therapy or who have an undetectable HIV viral load is still under debate 25 . The recommendation of elective caesarian for $40 \%$ of the pregnant women in this study could be the reflection of two factors: the high frequency of caesarian section, independent of HIV infection, or the diffusion of the knowledge among services caring for HIV-positive women that this type of delivery is a prophylactic measure. Evaluation of 
the risks and benefits of this measure is necessary to diminish the complications associated with this type of delivery.

The access to exams capable of evaluating the evolution of HIV infection (quantification of viral load and T lymphocytes CD4 count) can be considered a benchmark of quality in the prenatal follow-up of pregnant women infected with HIV. Know-how related to familiarity with maintenance or control of viral replication in pregnant women who receive antiretroviral therapy allows modifying or adapting the woman's therapy to reach the lowest HIV viral load at pregnancy term, which is known to be a fundamental factor in controlling virus transmission 14 .

Women testing positive for HIV have a greater risk of premature delivery (gestation $<37$ weeks) and for newborns with low weight $(<2,500 \mathrm{~g})$, and both variables have been found to be associated with mother-to-child transmission of HIV 19,34.

Despite orientation to prevent breastfeeding and providing formula for babies born of HIVinfected mothers, $6.4 \%$ of children whose mothers had been so informed were breastfed for up to 719 days. Sociocultural and economic factors may be responsible for the decision to breastfeed infants, which knowingly increases the risk of viral transmission 26 .

Children followed in the Northeastern Region were those that proportionately were more likely to be breastfed, but it was not possible to establish a direct association between the proportion of children breastfed and the mother-to-child transmission of HIV rates in each region.

In spite of its limitations in respect to health service selection from different geographic regions, the difficulties defining the infection status in children in due time, and the difficulties in obtaining adequate information for all the vari- ables evaluated, this study shows that it is necessary to keep strict epidemiological surveillance attention on HIV-positive pregnant women and their HIV exposed children, not only in regard to case reporting, but principally in regard to making sure that this population receives the care it is entitled to.

\section{Conclusion}

This study estimates that mother-to-child transmission of HIV in Brazil is falling, but the different rates encountered in each geographic region are evidence of diversity in social, cultural, economic, and access to health services. HIV infection in children should be regarded as an important indicator of the quality of obstetric and neonatal health care assistance in the country: elevated rates of vertical HIV transmission indicate a lack of prenatal care or lack of adherence to antiretroviral therapy by the mother.

The necessity of identifying all the women infected with HIV before or during pregnancy, the aim of giving full access to exams that permit the evaluation of their immunological and virological status during pregnancy, the proper guidance and use of antiretroviral therapy in order to control viral replication, and programming the type of delivery, will make possible further reductions in vertical HIV transmission in the country. The association made evident of vertical HIV transmission with lower birth weight and breastfeeding, dramatically demonstrates the importance of guaranteeing quality prenatal care and access of children to health services so they can receive proper management and care, and be offered a substitute for mother's milk, in addition to other prophylactic measures. 


\section{Resumo}

O objetivo do estudo foi descrever as taxas de transmissão vertical do HIV no Brasil nos anos de 2000 e 2001, e identificar as variáveis maternas e dos recém-nascidos associadas à transmissão. O estudo foi transversal, observacional, com dados retrospectivos obtidos por meio da análise de prontuários médicos em 63 serviços localizados nas cinco macrorregiões geográficas do país (vinte estados e o Distrito Federal). Foram consideradas, para o estudo, crianças nascidas de mães infectadas pelo HIV que apresentaram documentação da infecção pelo vírus antes ou durante a gestação, no momento da admissão para o parto ou nos três primeiros meses após o parto. Foram incluídas 2.924 crianças e a taxa de transmissão vertical do HIV foi: 8,6\% em 2000 (IC95\%: 7,2-10,2) e 7,1\% em 2001 (IC95\%: 5,8-8,6). As seguintes variáveis foram associadas com a transmissão vertical do HIV: parto cesárea eletiva, diagnóstico da infecção materna antes ou durante a gestação, acesso a exames de quantificação da carga viral do HIV e contagem de linfócitos-T CD4+ durante a gestação, peso ao nascimento e ausência de aleitamento materno.

Transmissão Vertical de Doença; HIV; Cuidado PréNatal

\section{Contributors}

R. C. M. Succi coordinated the group, collected and reviewed the data, wrote and edited the article. Grupo de Estudo da Sociedade Brasileira de Pediatria para Avaliar a Transmissão Materno-Infantil do HIV participated in data collection and follow-up of the children.
Other members of the Grupo de Estudo da Sociedade Brasileira de Pediatria para Avaliar a Transmissão Materno-infantil do HIV

G. I. Abdallah, T. Abreu, M. J. Aguiar, M. Alóe, M. Albuquerque, F. J. Almeida, V. C. Almeida, S. D. Andrade, S. B. Assis, R. M. A. Barbosa, R. M. G. H. Barbosa, V. M. C. Barros, E. N. Berezin, D. V. Bertolini, M. Buger, A. E. Campeas, A. P. Carvalho, B. M. Carvalho, M. Carvalho, R. M. Coelho, B. V. Costa, E. S. M. Costa, M. N. F. G. Costa, T. F. D'A. Costa, C. Cruz, K. S. A. Cunegundes, I. R. A. Dias, M. G. D. Diniz, C. F. Duarte, A. M. Faria, S. M. Faria, S. M. L. Fernandes, M. S. Ferrão, M. A. G. Ferrarini, M. A. Ferreira, S. M. A. Ferreira, R. C. Fonseca, R. P. Gianvecchio, A. S. P. Gibbons, I. M. Gomes, M. Gomes, N. Guarino, P. S. Guzzo, M. C. M. Hamaji, L. A. Hamamoto, M. I. S. Heyn, J. Hirano, A. H. Hiraoka, L. Hornke, V. F. Horta, L. Iwace, M. G. T. Jorge, S. C. Kummer, M. J. Lago, R. D. Leite, M. Lerner, A. P. N. B. Lima, M. S. O. Lins, C. Lorenzo, B. R. Lucarevschi, D. M. Machado, O. C. Mantese, H. H. Marques, S. R. Marques, L. H. Matida, M. A. N. Maurício, T. T. I. Miyake, M. M. Monteiro, L. M. O. Moreira, S. F. Moreira-Silva, F. Motta, J. Olbrich Neto, M. M. M. Neves, T. M. I. Nishimoto, S. A. Nogueira, B. K. Oliveira, N. C. Pacheco, E. M. B. Padrão, M. V. S. Pone, M. Prazinos, M. Radam, M. E. C. Raymundo, L. C. Rey, T. C. Ribeiro, A. Rímoli, V. S. C. Santana, E. S. Santos, V. P. Santos, A. Sanudo, C. L. O. Silva, M. H. Silva, M. M. Silva, M. M. G. Silva, E. Souza, M. V. Stump, D. C. N. Sztajnbok, T. C. C. Ventura, H. M. Vieira, M. M. S. Vilela, J. M. S. Voorham, E. A. Waldman, D. H. M. Xavier, E. P. Yamaguti e A. Zuliani.

\section{Acknowledgments}

This multicentric stiudy was only possible because each doctor in the participating services collaborated and made available for analysis the data of the mothers and babies. We would like to thank all those participants from the Grupo de Estudo da Sociedade Brasileira de Pediatria para Avaliar a Transmissão Materno-Infantil do HIV and for the financial support of the PNDST/ AIDS and UNESCO (United Nations Educational, Scientific, and Cultural Organization). 


\section{References}

1. Ministério da Saúde. Boletim Epidemiológico AIDS 2005; Ano II; no. 1.

2. Connor EM, Sperling RS, Gelber R, Kiselev P, Scott G, O'Sullivan MJ, et al. Reduction of maternal-infant transmission of human immunodeficiency virus type 1 with zidovudine treatment. Pediatric AIDS Clinical Trials Group Protocol 076 Study Group. N Engl J Med 1994; 331:1173-80.

3. Rates of mother-to-child transmission of HIV-1 in Africa, America and Europe: results from 13 perinatal studies. The Working Group on Mother-toChild Transmission of HIV. J Acquir Immune Defic Syndr Hum Retrovirol 1995; 8:506-10.

4. Mofenson LM, Lambert LS, Stiehm, ER, Bethel J, Meyer 3rd WA, Whitehouse J, et al. Risk factors for perinatal transmission of human immunodeficiency virus type 1 in women treated with zidovudine. Pediatric AIDS Clinical Trials Group Study 185 Team. N Engl J Med 1999; 341:385-93.

5. Lindegren ML, Byers Jr. RH, Thomas P, Davis SF Caldwell B, Rogers M, et al. Trends in perinatal HIV/AIDS in United States. JAMA 1999; 282:531-8.

6. European Collaborative Study. Mother-to-child transmission of HIV infection in the era of highly active antiretroviral therapy. Clin Infect Dis 2005; 40:458-65.

7. Cooper ER, Charurat M, Mofenson L, Hanson IC, Pitt J, Diaz C, et al. Combination antiretroviral strategies for the treatment of pregnant HIV-1-infected women and prevention of perinatal HIV-1 transmission. J Acquir Immune Defic Syndr 2002; 29:484-94.

8. Joint United Nations Programme on HIV/AIDS/ World Health Organization. HIV infection rates decreasing in several countries but global number of people living with HIV continues to rise. http:// www.who.int/hiv/epiupdate2005/en/index.html (accessed on 12/Aug/2006).

9. Matida LH, Silva MH, Tayra A, Succi RCM, Gianna MC, Gonçalves A, et al. Prevention of mother-tochild transmission of HIV in São Paulo State, Brazil: an update. AIDS 2005; 19 Suppl 4: S37-41.

10. Kreitchmann R, Fuchs SC, Suffert T, Preussler G. Perinatal HIV-1 transmission among low income women participants in the HIV/AIDS Control Program in Southern Brazil: a cohort study. BJOG 2004; 111:579-84.

11. Nishimoto TMI, Eluf Neto J, Rozman MA. Motherto-child transmission of human immunodeficiency virus (HIV-I): evaluation of control measures in the city of Santos. Rev Assoc Med Bras 2005; 51:5460.

12. Succi RCM, Kummer SC; Grupo de Estudo da Sociedade Brasileira de Pediatria para Avaliar a Transmissão Materno-Infantil do HIV. Avaliação de um programa para reduzir taxas de transmissão vertical do HIV no Brasil. Resultados de um estudo colaborativo multicêntrico. An Pediatr (Barc) 2004; 60 Suppl 3:80-1.

13. Programa Nacional de DST e AIDS, Ministério da Saúde. Recomendações para prevenção da transmissão vertical do HIV e terapia anti-retroviral para gestantes. Brasília: Ministério da Saúde; 2006.
14. Programa Nacional de DST e AIDS, Ministério da Saúde. Guia de tratamento clínico da infecção pelo HIV em crianças. Brasília: Ministério da Saúde; 2004.

15. Thorne C, Newell ML. Prevention of mother-tochild transmission of HIV infection. Curr Opin Infect Dis 2004; 17:247-52.

16. Newell ML. Current issues in the prevention of mother-to-child transmission of HIV-1 infection. Trans R Soc Trop Med Hyg 2006; 100:1-5.

17. Nogueira SA, Abreu T, Oliveira R, Araújo L, Costa $\mathrm{T}$, Andrade M, et al. Successful prevention of HIV transmission from mother to infant in Brazil using a multidisciplinary team approach. Braz J Infect Dis 2001; 5:78-86.

18. Dal Fabbro MMFJ, Paniago AMM, Lindenberg ASC, Freitas GMB, Nogueira SA. Prospective study on the prevention of vertical transmission of HIV in Campo Grande, Mato Grosso do Sul, Brazil, from 1996 to 2001. Braz J Infect Dis 2005; 9:20-7.

19. João EC, Cruz ML, Menezes JA, Matos HJ, Calvet GA, d'Ippolito MM, et al. Vertical transmission of HIV in Rio de Janeiro, Brazil. AIDS 2003; 17:1853-5.

20. Tess BH, Rodrigues LC, Newell ML, Dunn DT, Lago TD. Breastfeeding, genetic, obstetric and other risk factors associated with mother to child transmission of HIV-1 in São Paulo State, Brazil. São Paulo Collaborative Study for Vertical Transmission of HIV-1. AIDS 1998; 12:513-20.

21. Mussi-Pinhata MM, Kato CM, Duarte G, Paschoini MC, Bettiol H, Quintana SM. Factors associated with vertical HIV transmission during two different time periods: the impact of zidovudine use on clinical practice at a Brazilian reference centre. Int J STD AIDS 2003; 14:818-25.

22. Magder LS, Mofenson L, Paul ME, Zorrilla CD, Blattner WA, Tuomala RE, et al. Risk factors for in utero and intrapartum transmission of HIV. J Acquir Immune Defic Syndr 2005; 38:87-95.

23. Mofenson LM, Munderi P. Safety of antiretroviral prophylaxis of perinatal transmission for HIV-infected pregnant women and their infants. J Acquir Immune Defic Syndr 2002; 30:200-15.

24. European Collaborative Study; Swiss Mother and Child HIV Cohort Study. Combination antiretroviral therapy and duration of pregnancy. AIDS 2000; 14:2913-20.

25. Read JS, Newell ML. Efficacy and safety of cesarean delivery for prevention of mother-to-child transmission of HIV-1. (Cochrane Review) In: The Cochrane Library, Issue 4, 2005. Oxford: Update Software.

26. Richardson BA, John-Stewart GC, Hughes JP, Nduati R, Mbori-Ngacha D, Overbaugh J, et al. Breastmilk infectivity in human immunodeficiency virus type 1-infected mothers. J Infect Dis 2003; 187:73640.

Submitted on 15/May/2006

Final version resubmitted on 18/Aug/2006

Approved on 31/Aug/2006 